\title{
Evaluation of four polymerase chain reaction primer pairs for the detection of Edwardsiella tarda in turbot
}

\author{
N. Castro*, A. E. Toranzo, S. Núñez, C. R. Osorio, B. Magariños \\ Departamento de Microbiología y Parasitología, Facultad de Biología/CIBUS e Instituto de Acuicultura, \\ Universidad de Santiago de Compostela, 15782 Santiago de Compostela, Spain
}

\begin{abstract}
Edwardsiella tarda is an important emergent pathogen in European aquaculture, causing several mortality events in turbot Scophthalmus maximus cultures in recent years. Here, we evaluated in parallel the specificity of 4 previously published pairs of primers, gyrBF1/gyrBR1, tardaF/ tardaR, etfA and etfD, for the detection of 53 E. tarda strains isolated from different sources, as well as 18 representatives of related and unrelated bacterial species. On the basis of the obtained results, we selected the pair of primers etfD, because it was the only one that recognized all E. tarda strains without false positive reactions. The sensitivity of this primer set showed detection limits of 2 cells per reaction tube in the case of pure cultures and 200 cells per reaction tube in mixed cultures. With regard to the sensitivity in seeded turbot tissues (kidney, liver and mucus), the detection limit was $3 \times 10^{2}$ E. tarda cells per reaction. In experimentally infected turbot, the etfD primer set was able to

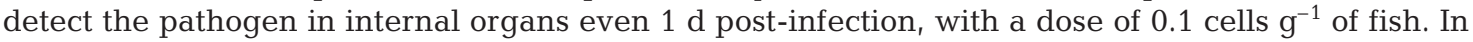
addition, this polymerase chain reaction protocol was useful for the detection of $E$. tarda in the field, and, based on the findings, we propose it as the most appropriate for accurate detection of E. tarda in routine diagnosis of edwardsiellosis in fish.
\end{abstract}

KEY WORDS: Edwardsiella tarda $\cdot \mathrm{PCR} \cdot$ Detection $\cdot$ Diagnosis $\cdot$ Turbot

\section{INTRODUCTION}

Edwardsiella tarda is a gram-negative bacterium, a member of the family Enterobacteriaceae and an important pathogen causing enterohaemorrhagic septicaemic disease in a variety of organisms, including amphibians, reptiles, fish, marine mammals and humans. This disease, also called edwardsiellosis, is a serious systemic bacterial disease that has a worldwide distribution in fresh and marine water, causing mortalities in important aquaculture species such as eel Anguila japonica, flounder Paralichthys olivaceus and catfish Ictalurus punctatus, among others (Sakazaki \& Tamura 1992, Plumb 1999).

In recent years, repeated outbreaks of edwardsiellosis have been detected in several turbot Scophthalmus maximus cultures in Europe, causing important economic losses (Castro et al. 2006, Toranzo 2007, Castro 2008). Although classical bacteriological and serological analyses give accurate and effective identification, rapid, specific and sensitive detection techniques that allow diagnosis of edwardsiellosis could represent an important advance in the prevention of the disease.

The polymerase chain reaction $(\mathrm{PCR})$ is a DNAbased method that is used for the detection of many marine pathogens (Osorio \& Toranzo 2002, Toranzo et al. 2004). Although in many PCR protocols the primers employed have been designed using the $16 \mathrm{~S}$ ribosomal RNA (rRNA) gene as a target, the application of the $16 \mathrm{~S}$ rRNA sequence is not always advisable, since it is highly conserved. In fact, in the case of Edwardsiella tarda, its 16S sequence shares identity of 96 to $100 \%$ in BLAST (Basic Local Alignment Search Tool, National Center for Biotechnology Information) with other 
species of the same genus, such as E. ictaluri and $E$. hoshinae, or with species of different genera, such as Pseudomonas fluorescens and Serratia marcescens.

In 1998, Chen and Lai designed a pair of primers that used the haemolysin gene as a target to detect Edwardsiella tarda, generating an 1109 bp product in the open reading frame (ORF) II and III regions (Chen \& Lai 1998). Several E. tarda strains were employed, most of which were isolated from infected eels and from experimentally infected tilapia and water. In 2007, Sakai et al. developed 4 primer sets (etfA, etfB, etfC and etfD) targeting the Type 1 fimbrial gene cluster of $E$. tarda to determine the presence of such fimbrial genes among the fish pathogenic and non-pathogenic strains of this bacterium isolated from Japanese fish (Sakai et al. 2007). Only 2 primer sets (etfA and etfD) showed an ability to detect E. tarda. Recently, Lan et al. (2008), designed a set of primers (gyrBF1 and gyrBR1) based on the sequence of the divergent region of the partial gyrB gene of an unusual E. tarda strain isolated from turbot in China. This set of primers generated a specific PCR product of $415 \mathrm{bp}$.

However, these pairs of primers have not yet been tested simultaneously in order to compare their specificity using a wide range of strains isolated from different hosts and geographical origins. Therefore, the aim of the present study was to evaluate the specificity and sensitivity of the 3 PCR methods described previously, in order to identify the best protocol for the detection of Edwardsiella tarda in fish, with special emphasis on the diagnosis of turbot edwardsiellosis.

\section{MATERIALS AND METHODS}

Bacterial strains. The bacterial strains used in the primer specificity studies are listed in Table 1 . This collection comprises 36 Edwardsiella tarda isolates from turbot in different outbreaks from 2004 to 2008, 17 E. tarda strains from other sources, as well as 18 isolates of other enterobacteria and marine fish pathogens (Table 1).

Strains were routinely cultured on Tripticase Soy Agar supplemented with $1 \%$ of $\mathrm{NaCl}$ (TSA-1; Pronadisa) and incubated at 25 or $37^{\circ} \mathrm{C}$, depending on the strain, for $24 \mathrm{~h}$. Before the assays, all bacterial strains were confirmed employing biochemical and serological tests (Thoesen 1994, Castro et al. 2006). Stock cultures were stored at $-70^{\circ} \mathrm{C}$ in Cryo-Bille tubes (AES Laboratory).

DNA extraction from bacterial cultures. Chromosomal DNA was extracted employing Insta-Gene Matrix (Bio-Rad) from bacterial cultures, following the recommendations of Bio-Rad, and eluted in a final volume of $200 \mu \mathrm{l}$ of Insta-Gene Matrix. All DNA concentrations were examined at $260 \mathrm{~nm}$ and adjusted to between 10 and $20 \mathrm{ng}^{-1} \mathrm{l}^{-1}$. DNA was maintained at $-30^{\circ} \mathrm{C}$ until used for PCR reactions. All the experiments were carried out with DNA obtained in 3 different extractions for each bacterial strain.

DNA amplification. All PCR amplifications were performed employing commercial Ready-To-Go PCR beads (Amersham Pharmacia Biotech), which included all the reagents needed for the PCR reactions with the exception of the specific primers and DNA template. Four species-specific primer pairs described by Chen \& Lai (1998), Sakai et al. (2007) and Lan et al. (2008) were synthesized by Sigma-Genosys and employed in this work for the identification of Edwardsiella tarda (see Table 2).

One microlitre of each DNA solution and $1 \mu \mathrm{l}$ of each primer $(100 \mu \mathrm{M})$ were used in the amplification reactions. Reaction mixtures $(25 \mu \mathrm{l})$ were amplified in 2 different thermal cyclers: the T Gradient Termocicler (Biometra) and the $\mathrm{T}$ Professional Basic (Biometra). The amplification cycles used for denaturation, primer annealing to the template and primer extension were carried out according to each published protocol. Negative controls, consisting of the same reaction mixture but with sterile distilled water instead of template DNA, were included in each batch of PCR reaction. The reproducibility of the results was assessed by repetition of the amplifications in 3 independent PCR assays.

In addition, as a positive control, the universal primers pA (5'-AGA GTT TGA TCC TGG CTC AG-3') and $\mathrm{pH}$ (5'-AAG GAG GTG ATC CAG CCG CA-3') (Edwards et al. 1989) were employed to detect the 16S rDNA in all strains.

Analysis of PCR products. Amplified products were detected by horizontal $1 \%(\mathrm{w} / \mathrm{v})$ agarose gel electrophoresis for $60 \mathrm{~min}$ at $100 \mathrm{~V}$ in TAE (Tris-acetateEDTA) $1 \times(0.04 \mathrm{M}$ Tris, $1 \mathrm{mM}$ EDTA [ethylenediaminetetraacetic acid], $\mathrm{pH}$ 8.0) electrophoresis buffer, visualized using $0.06 \mathrm{\mu g} \mathrm{ml}^{-1}$ of ethidium bromide (BioRad), photographed under UV light and computer digitised (Gel Doc 100, Bio-Rad). A 50 to 2000 bp ladder (Sigma Chemical Co.) was used as a molecular mass marker. The presence of a single product of the appropriate size was considered as a positive result.

Sensitivity of the PCR. On the basis of the obtained results comparing the ability of each primer pair tested to amplify Edwardsiella tarda from all sources, we selected the primer pair etfD and evaluated its sensitivity with respect to $E$. tarda detection. The detection limit of this primer set was evaluated employing pure E. tarda and E. tarda cultures mixed with other fish pathogens.

From pure cultures of 3 selected Edwardsiella tarda strains (2 turbot isolates and NCIMB2034), colonies were picked from TSA-1 plates, visually adjusted to 
Table 1. Bacterial strains included in the present study, and the results from the specific polymerase chain reaction detection methods employed. Primer sets show number of strains detected with each primer set. NCIMB: National Collection of Marine and Industrial Bacteria (Aberdeen, UK); CECT: Colección Española de Cultivos Tipo (Valencia, Spain); ATCC: American Type Culture Collection (Rockville, USA); DSM: Deutsche Sammlung von Mikroorganismen (Braunschweig, Germany)

\begin{tabular}{|c|c|c|c|c|c|c|}
\hline Strain & Source & $\begin{array}{l}\text { No. of } \\
\text { strains }\end{array}$ & gyrBF1/gyrBR1 & $\begin{array}{l}\text { Primer sets } \\
\text { tardaF/tardaR }\end{array}$ & etfA & etfD \\
\hline \multicolumn{7}{|l|}{ Edwardsiella tarda strains } \\
\hline Turbot & Scophthalmus maximus & 36 & 0 & 0 & 35 & 36 \\
\hline Gilthead seabream & Sparus aurata & 1 & 0 & 0 & 0 & 1 \\
\hline Japanese eel & Anguilla japonica & 2 & 0 & 2 & 2 & 2 \\
\hline Catfish & Ictalurus punctatus & 1 & 0 & 0 & 1 & 1 \\
\hline Striped bass & Morone saxatilis & 2 & 0 & 0 & 2 & 2 \\
\hline Pacific salmon & Oncorhynchus kisutch & 1 & 0 & 0 & 0 & 1 \\
\hline Angel fish & Pterophyllum scalare & 1 & 0 & 0 & 0 & 1 \\
\hline Tilapia & Oreochromis niloticus & 2 & 0 & 2 & 2 & 2 \\
\hline Japanese flounder & Paralichthys olivaceus & 2 & 0 & 2 & 2 & 2 \\
\hline Red seabream & Pagrus major & 3 & 0 & 3 & 3 & 3 \\
\hline E. tarda NCIMB2034 & Unknown fish & 1 & 0 & 1 & 1 & 1 \\
\hline E. tarda CЕСТ849 & Human faeces & 1 & 0 & 1 & 1 & 1 \\
\hline \multicolumn{7}{|l|}{ Other bacterial strains } \\
\hline Edwardsiella ictaluri ATCC33202 & Ictalurus punctatus & 1 & 0 & 0 & 1 & 0 \\
\hline Edwardsiella ictaluri B1.1 & Chondrostoma polylepis & 1 & 0 & 1 & 0 & 0 \\
\hline Edwardsiella hoshinae DSM13771 & Fratercula sp. & 1 & 0 & 0 & 1 & 0 \\
\hline Escherichia coli CECT433 & Human & 1 & 0 & 0 & 1 & 0 \\
\hline Enterobacter cloacae TW83/03 & Oncorhynchus mykiss & 1 & 0 & 0 & 0 & 0 \\
\hline Enterobacter aerogenes RPM799.1 & Scophthalmus maximus & 1 & 0 & 0 & 1 & 0 \\
\hline Yersinia ruckeri 1651 & Oncorhynchus mykiss & 1 & 0 & 0 & 1 & 0 \\
\hline Yersinia ruckeri SRG4.1 & Oncorhynchus mykiss & 1 & 0 & 0 & 1 & 0 \\
\hline Hafnia alvei $15 / 1403$ & Oncorhynchus mykiss & 1 & 0 & 0 & 0 & 0 \\
\hline Serratia marcescens PC955.1 & Scophthalmus maximus & 1 & 0 & 0 & 0 & 0 \\
\hline $\begin{array}{l}\text { Aeromonas salmonicida ssp. } \\
\text { salmonicida ACR218.1 }\end{array}$ & Scophthalmus maximus & 1 & 0 & 0 & 1 & 0 \\
\hline Listonella (Vibrio) anguillarum R82 & Scophthalmus maximus & 1 & 0 & 0 & 0 & 0 \\
\hline $\begin{array}{l}\text { Photobacterium damselae ssp. } \\
\text { piscicida ATCC } 29690\end{array}$ & Seriola quinqueradiata & 1 & 0 & 0 & 0 & 0 \\
\hline Pseudomonas anguilliseptica СЕСТ899 & Anguilla japonica & 1 & 0 & 0 & 0 & 0 \\
\hline Pseudomonas fluorescens 07/1139 & Oncorhynchus mykiss & 1 & 0 & 0 & 0 & 0 \\
\hline Pseudomonas aeruginosa CECT110 & Unknown & 1 & 0 & 0 & 0 & 0 \\
\hline Lactococcus garvieae SRG1.1 & Oncorhynchus mykiss & 1 & 0 & 0 & 0 & 0 \\
\hline Streptococcus parauberis ACC33.1 & Scophthalmus maximus & 1 & 0 & 0 & 0 & 0 \\
\hline
\end{tabular}

Table 2. Primer sets employed in the present study for the detection of Edwardsiella tarda

\begin{tabular}{|c|c|c|c|c|}
\hline Primer set & $\begin{array}{c}\text { Positions } \\
\text { (encoding protein) }\end{array}$ & Target gene & $\begin{array}{l}\text { Predicted product } \\
\text { size (bp) }\end{array}$ & Source \\
\hline \multicolumn{5}{|l|}{ tardaF/tardaR } \\
\hline 5'-CCT TAT AAA TTA CTC GCT-3' & $744-761$ & ORFII-ORFIII & 1109 & Chen \& Lai (1998) \\
\hline 5'-TTT GTG GAG TAA CAG TTT-3' & $1850-1833$ & (haemolysin) & & \\
\hline \multicolumn{5}{|l|}{ etfA } \\
\hline 5'-CGG TAA AGT TGA GTT TAC GGG TG-3' & $2160-2182$ & etfA (major & 415 & Sakai et al. (2007) \\
\hline 5'-TGT AAC CGT GTT GGC GTA AG-3' & $2555-2574$ & fimbrial subunit) & & \\
\hline \multicolumn{5}{|l|}{ etfD } \\
\hline 5'-GGT AAC CTG ATT TGG CGT TC-3' & $6171-6190$ & etfD (fimbrial & 445 & Sakai et al. (2007) \\
\hline 5'-GGA TCA CCT GGA TCT TAT CC-3' & $6596-6615$ & subunit) & & \\
\hline \multicolumn{5}{|l|}{ gyrBF1/gyrBR1 } \\
\hline 5'-GCA TGG AGA CCT TCA GCA AT-3' & $242-262$ & gyrB & 415 & Lan et al. (2008) \\
\hline 5'-GCG GAG ATT TTG CTC TTC TT-3' & $637-656$ & (gyrase) & & \\
\hline
\end{tabular}


contain $10^{9}$ cells $\mathrm{ml}^{-1}$ (corresponding to McFarland Scale 4 ) and serially diluted in $0.85 \%$ sterile saline solution (SS) from $10^{8}$ to 10 cells $\mathrm{ml}^{-1}$.

To determine the usefulness of the etfD primers to amplify template Edwardsiella tarda DNA from mixed cultures, bacterial suspensions of Listonella (Vibrio) anguillarum (R82) and Aeromonas salmonicida ssp. salmonicida (ACR218.1) were employed. We selected these bacterial species because both are some of the most common and important pathogens in turbot aquaculture. Bacterial mixtures simultaneously including these 2 pathogens and E. tarda (turbot strain ACC35.1) were prepared by mixing $500 \mu \mathrm{l}$ of each bacterial suspension, previously adjusted at a concentration of $10^{7}$ cells $\mathrm{ml}^{-1}$, and were serially diluted. All dilutions were centrifuged at $12000 \mathrm{rpm}$ for 2 min and washed twice with sterile distilled water. Extraction and amplification of genomic DNA, as well as the analysis of the PCR products, were performed as described before. Colony-forming units (CFU) were estimated by plating each dilution onto TSA-1 plates and counting the produced bacterial colonies.

Applicability to fish tissues. To determine the applicability of the etfD primer set in the detection of Edwardsiella tarda in fish tissues, different samples including kidney, liver, intestine, blood and mucus were obtained from healthy turbot (10 to $12 \mathrm{~g}$ weight), which were analysed by bacteriological standard methods (Thoesen 1994) to confirm the absence of pathogens that could interfere in the experiments. Samples of $1 \mathrm{~g}$ of each tissue (liver and kidney) were then homogenized respectively in $100 \mu \mathrm{l}$ of phosphate-buffered saline (PBS, pH 7.4) by repeated pipetting. In the case of blood and mucus, the volume employed was $200 \mu l$. Each fish sample was seeded with $100 \mu \mathrm{l}$ of the different dilutions of the E. tarda turbot strain ACC35.1 and homogenized. After incubation for $1 \mathrm{~h}$ at $25^{\circ} \mathrm{C}$, DNA extraction was performed with the Easy-DNA kit for genomic DNA isolation (Invitrogen) following the manufacturer's recommendations. DNA was maintained at $-30^{\circ} \mathrm{C}$ until use in PCR reactions. DNA from non-seeded fish samples, and PBS were extracted in the same manner for use as negative controls.

In addition, tissues from 2 batches of 50 turbot (10 to $12 \mathrm{~g}$ weight) injected with Edwardsiella tarda strain ACC 35.1 at a concentration of $0.1 \mathrm{ml}$ of $10^{2} \mathrm{CFU} \mathrm{ml}^{-1}$ (1 CFU g ${ }^{-1}$ of fish) and $10 \mathrm{CFU} \mathrm{ml} l^{-1}\left(0.1 \mathrm{CFU} \mathrm{g}^{-1}\right.$ of fish), respectively, were used to test the etfD PCR assay. The E. tarda strain employed in these challenges was again the isolate ACC 35.1, with a $\mathrm{LD}_{50}$ of $1.6 \times$ $10^{1}$ cells ml ${ }^{-1}$ (Toranzo 2007). For the control group, the same number of fish were injected with $0.1 \mathrm{ml}$ of SS and maintained at the same conditions as infected fish. Fish were maintained in $50 \mathrm{l}$ aquaria with continuous aeration and water temperature of approximately $17^{\circ} \mathrm{C}$. Samples of kidney, liver, spleen, intestine, blood and mucus were collected from 10 turbot before inoculation and at 1, 2 and $5 \mathrm{~d}$ post-inoculation, and pools of each tissue type were prepared per time point. DNA was extracted with the Easy-DNA kit for genomic DNA isolation (Invitrogen) and eluted in a final volume of $100 \mu \mathrm{l}$ of TE buffer. Then, $1 \mu \mathrm{l}$ of DNA was employed as template in the PCR assay. Classical bacteriological analysis, by standard plate culture techniques and further biochemical and serological identification, was performed in order to assess the ability to detect $E$. tarda by this method in the challenged fish.

Field validation. A total of 80 diseased turbot ranging from 50 to $200 \mathrm{~g}$ coming from natural outbreaks in 3 different rearing facilities, as well as a similar number of apparently healthy fish sent to our laboratory for routine analysis, were tested using the etfD PCR assay. Tissue samples (kidney, spleen, liver and intestine), as well as blood and mucus, were analysed. Conditions for DNA extraction and PCR amplification were the same as described above. In parallel, classical bacteriological analyses were performed in order to confirm the presence or absence of Edwardsiella tarda.

\section{RESULTS}

\section{PCR specificity}

To test the specificity of each pair of primers for Edwardsiella tarda identification, DNA extracted from a collection of 71 strains, including $E$. tarda and non-E. tarda isolates were used in PCR reactions with each primer pair (Table 1). When the primers tardaF/tardaR were employed, the expected amplification product was obtained in only $21 \%$ of the strains used in the present study. In fact, only strains isolated from Japanese eel and flounder, tilapia, red seabream and the reference strain CECT 849 from human faeces generated the 1109 bp PCR-fragment, and no isolate from turbot Scophthalmus maximus showed the expected amplification product. Moreover, non-specific amplification was observed with DNA template from E. ictaluri. With regard to the primers etfA, the expected $415 \mathrm{bp}$ band was not amplified in $4 E$. tarda strains isolated from turbot, gilthead seabream, Pacific salmon and angel fish. In addition, these etfA primers produced non-specific amplification with non-E. tarda strains. PCR amplification with the set of primers gyrBF1/gyrBR1 did not yield PCR products in any of the strains tested. In contrast to the other 3 PCR primer pairs tested, the primer set etfD identified all the E. tarda isolates, and no cross-amplification with other bacterial species was detected. Based on these results, only the primer pair etfD was selected for subsequent studies. 
Reproducibility of PCR was demonstrated, since the same results were obtained in, at least, 3 independent PCR assays for each primer set tested and using 2 different thermal cyclers. As expected, the universal primers $\mathrm{pA} / \mathrm{pH}$ yielded a PCR product of the predicted size (1501 bp) in all strains tested (data not shown).

\section{Determination of PCR sensitivity from pure and mixed cultures}

The sensitivity of the etfD primer pair was determined by amplification of the DNA extracted from different bacterial suspensions $\left(10^{8}\right.$ to $\left.10 \mathrm{CFU} \mathrm{ml}^{-1}\right)$ of Edwardsiella tarda strains in pure and mixed cultures. The expected 445 bp PCR product was obtained with samples containing as low as 2 cells per PCR reaction tube $(2 \times$ $10^{3} \pm 0.2 \mathrm{CFU} \mathrm{ml} \mathrm{m}^{-1}$ ) in the case of pure cultures (Fig. 1a) and 200 cells per PCR reaction tube $\left(2 \times 10^{5} \pm 0.2 \mathrm{CFU}\right.$ $\mathrm{ml}^{-1}$ ) in the case of mixed cultures (Fig. 1b).

\section{Determination of PCR sensitivity from seeded tissues and experimentally infected fishes}

The application of the etfD PCR protocol to DNA templates obtained from fish tissues seeded with different concentrations of Edwardsiella tarda showed that this pathogen can be detected in kidney, liver and mucus at a detection level of $3 \times 10^{2} \mathrm{CFU}$ per reaction tube $\left(3 \times 10^{5}\right.$ CFU g ${ }^{-1}$ fish tissue or $\mathrm{ml}^{-1}$ of mucus) (Fig. 1c). When blood was employed, the detection limit was $3 \times 10^{5} \mathrm{CFU}$ per tube of reaction $\left(3 \times 10^{8} \mathrm{CFU} \mathrm{ml}^{-1}\right.$ of blood $)$.

The PCR assay was also applied to kidney, liver, spleen, intestine, blood and mucus samples obtained from experimentally inoculated turbot with doses of 1 and $10 \mathrm{CFU}$ fish $^{-1}$. Edwardsiella tarda was detected by PCR from the internal organs of all infected fish, even $1 \mathrm{~d}$ post-inoculation and with the lower concentration
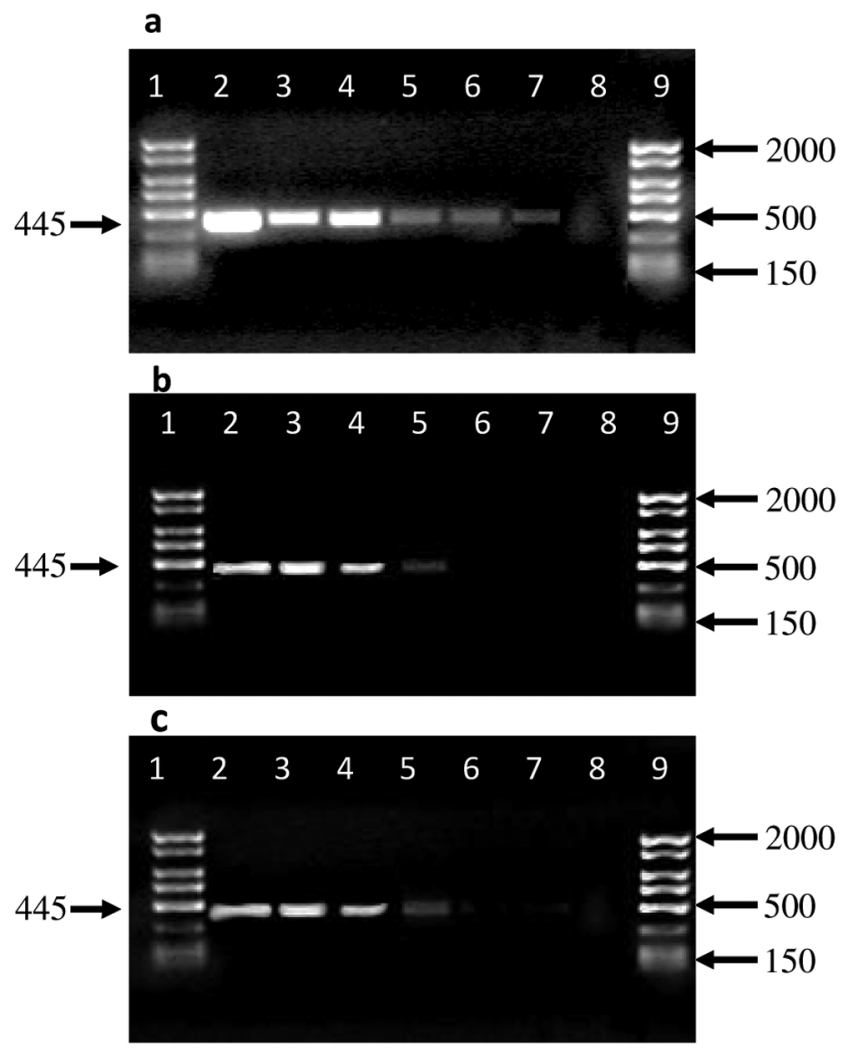

Fig. 1. Sensitivity of the polymerase chain reaction protocol using purified DNA from serial dilutions of (a) a pure culture of Edwardsiella tarda strain ACC35.1, (b) mixed cultures and (c) from seeded samples of kidney. Lanes 1 and 9: AmpliSize Molecular Ruler (50 to 2000 bp ladder; Sigma); (a,b) Lanes 2 to 8: dilutions ranging from $2 \times 10^{8} \mathrm{CFU}$ (colony-forming units) $\mathrm{ml}^{-1}$ (Lane 2) to $2 \times 10^{2} \mathrm{CFU} \mathrm{ml}^{-1}$ (Lane 8). (c) Lanes 2 to 8: dilutions ranging from $3 \times 10^{8} \mathrm{CFU} \mathrm{ml}^{-1}$ (Lane 2) to $3 \times 10^{2}$ CFU ml ${ }^{-1}$ (Lane 8). Numbers on the left indicate the specific amplified product in basepairs

of bacteria inoculated, but not from blood or mucus (Table 3). No amplification was observed in tissues from the PBS-inoculated fish used as negative controls.

Table 3. Detection of Edwardsiella tarda in experimentally inoculated (at doses of 1 and 100 colony-forming units [CFU] fish ${ }^{-1}$ ) and in naturally infected turbot by polymerase chain reaction (PCR) and by classical bacteriological analysis using standard culture methods (C) (+: positive detection; -: negative detection; dpi: days post-infection). All apparently healthy fishes showed negative results for PCR amplification and classical bacteriological analysis

\begin{tabular}{|c|c|c|c|c|c|c|c|c|c|c|c|c|c|c|}
\hline \multirow{3}{*}{ Samples } & \multicolumn{12}{|c|}{ Experimental infection } & \multirow{2}{*}{\multicolumn{2}{|c|}{$\begin{array}{c}\text { Naturally } \\
\text { infected } \\
\text { samples }\end{array}$}} \\
\hline & \multicolumn{2}{|c|}{$1 \mathrm{dpi}$} & \multicolumn{2}{|c|}{$\begin{array}{c}1 \mathrm{CFU} \mathrm{fish}^{-1} \\
2 \mathrm{dpi}\end{array}$} & \multicolumn{2}{|c|}{$5 \mathrm{dpi}$} & \multicolumn{2}{|c|}{$1 \mathrm{dpi}$} & \multicolumn{2}{|c|}{$\begin{array}{c}10 \mathrm{CFU} \mathrm{fish}^{-1} \\
2 \mathrm{dpi}\end{array}$} & \multicolumn{2}{|c|}{$5 \mathrm{dpi}$} & & \\
\hline & PCR & $\mathrm{C}$ & PCR & $\mathrm{C}$ & PCR & $\mathrm{C}$ & PCR & $\mathrm{C}$ & PCR & $\mathrm{C}$ & PCR & $\mathrm{C}$ & PCR & $\mathrm{C}$ \\
\hline Kidney & + & - & + & - & + & - & + & - & + & - & + & - & + & + \\
\hline Liver & + & - & + & - & + & - & + & - & + & - & + & - & + & + \\
\hline Intestine & + & - & + & - & + & - & + & - & + & - & + & - & + & + \\
\hline Spleen & + & - & + & - & + & - & + & - & + & - & + & - & + & + \\
\hline Blood & - & - & - & - & - & - & - & - & - & - & - & - & + & + \\
\hline Mucus & - & - & - & - & - & - & - & - & - & - & - & - & - & - \\
\hline
\end{tabular}


By classical bacteriological analysis, E. tarda colonies were not detected on agar plates when samples from internal organs, blood and mucus were plated.

\section{Field validation}

In the case of the samples obtained from naturally infected turbot coming from 3 different rearing facilities, Edwardsiella tarda was detected in all internal organs and blood, producing the specific etfD PCR product $(445 \mathrm{bp})$. However, no amplification was observed when the mucus samples of these fish were employed (Table 3). In all cases of infected fish, E. tarda was isolated on TSA-1 plates using homogenates from all internal organs and blood, but not from mucus, and was identified by biochemical and serological tests. Neither isolation of the pathogen, nor PCR amplification occurred when the apparently healthy turbot were analysed. The total time for the PCR procedure, including DNA extraction from samples, amplification and gel electrophoresis, was shorter than $6 \mathrm{~h}$.

\section{DISCUSSION}

Edwardsiella tarda is an important emerging bacterial pathogen in turbot Scophthalmus maximus culture causing high and rapid mortalities in this fish species (Castro et al. 2006, Toranzo 2007). Therefore, there is an urgent need to develop a sensitive and accurate method for the fast detection of this bacterium, in both infected and carrier fish. Moreover, the application of this technique to environmental samples could be of great importance to determine reservoirs of E. tarda.

DNA-based methods have been developed in recent years for the fast and sensitive diagnosis of pathogens of many aquatic species (Toranzo et al. 2005). In the present study, we evaluated in parallel the effectiveness of the primers tardaF and tardaR from Chen \& Lai (1998), 2 selected sets of primers (etfA and etfD) from Sakai et al. (2007) and the pair of primers gyrBF1/ gyrBR1 from Lan et al. (2008) in order to assess the best PCR protocol to identify and detect Edwardsiella tarda from both pure and mixed cultures, as well as in fish and environmental samples. For this, we employed a collection of E. tarda strains with a wide range of host and geographical origins, as well as a collection of related and unrelated bacterial isolates. The obtained results demonstrated that only the primer pair etfD was specific for E. tarda detection. The lack of amplification in all strains employed in the present study when the primers gyrBF1 and gyrBR1 were used is explained by the fact that the sequences of these primers, published by Lan et al. (2008), show 4 and 2 mismatches, respectively, with the $\operatorname{gyr} B$ sequence reported for E. tarda NCIMB2034 (GenBank accession number EU259314.1). These mismatches together would be enough to prevent amplification of the $\operatorname{gyr} B$ gene in E. tarda strains whose sequence differs from that of the unusual strain LTB-4.

Sensitivity for the primer set etfD was about 2 and 200 CFU per tube of reaction in the case of pure and mixed cultures, respectively, and $300 \mathrm{CFU}$ in seeded tissues and mucus. The sensitivity obtained for the etfD PCR assay for Edwardsiella tarda is comparable to those obtained for other bacterial fish pathogens (Osorio et al. 1999, Romalde et al. 2004, Avendaño-Herrera et al. 2004). However, the detection limit in blood was in the order of $3 \times 10^{5} \mathrm{CFU}$ per tube of reaction, which could be considered a poor value for its applicability as a non-destructive diagnostic procedure for the detection of carrier fish of E. tarda.

In addition, when experimental infection of turbot was developed, we could detect Edwardsiella tarda by PCR from the internal organs of inoculated fish, but not from the mucus or blood. Based on this, we propose the kidney as a target organ for the detection of carrier animals of E. tarda. The failure to detect the bacterium by conventional microbiological culture could be due to the period of study ( $5 \mathrm{~d}$ ). In fact, we have previously demonstrated that mortalities caused by E. tarda in turbot inoculated with doses $<10^{4} \mathrm{CFU} \mathrm{ml} \mathrm{m}^{-1}$ start on Day 12 post-inoculation (Toranzo 2007).

On the other hand, the analysis of naturally infected turbot received in our laboratory showed that, when the infection is already present in fish, PCR and bacteriological protocols allow the detection of Edwardsiella tarda from all samples tested except mucus. The negative PCR detection in this type of sample could be explained by recent studies in our laboratory in which the antibacterial activity of mucus against E. tarda was demonstrated (data not shown).

In summary, we propose the PCR protocol employing the primer set etfD (Sakai et al. 2007) as a rapid and sensitive method for the accurate detection of Edwardsiella tarda in infected fish.

Acknowledgements. This work was supported in part by Grants 08MMA018E and AGL2009-08859 from Xunta de Galicia and Ministerio de Ciencia e Innovación (Spain), respectively. The authors thank Insuíña SL for the kind supply of fish for the experimental assays, as well as the different donors of the strains used in this work. N. Castro also thanks the Universidad de Santiago de Compostela (Spain) for a predoctoral fellowship.

\section{LITERATURE CITED}

Avendaño-Herrera R, Magariños B, Toranzo AE, Beaz R, Romalde JL (2004) Species-specific polymerase chain 
reaction primer sets for the diagnosis of Tenacibaculum maritimum infection. Dis Aquat Org 62:75-83

Castro N (2008) Edwardsiella tarda en rodaballo: virulencia y estrategias de vacunación. Master thesis, Universidad de Vigo, Vigo

Castro N, Toranzo AE, Barja JL, Núñez S, Magariños B (2006) Characterization of Edwardsiella tarda strains isolated from turbot, Psetta máxima (L.). J Fish Dis 29:541-547

Chen J, Lai S (1998) PCR for direct detection of Edwardsiella tarda from infected fish and environmental water by application of the hemolysin gene. Zool Stud 37:169-176

Edwards U, Rogall T, Bloecker H, Emde M, Boettger EC (1989) Isolation and direct complete nucleotide determination of entire genes. Characterization of a gene coding for 16S ribosomal RNA. Nucleic Acids Res 28:1942-1946

Lan J, Zhang ZH, Wang Y, Chen J, Han Y (2008) Isolation of an unusual strain of Edwardsiella tarda from turbot and establish a PCR detection technique with the gyrB gene. J Appl Microbiol 105:644-651

Osorio CR, Toranzo AE (2002) DNA-based diagnostics in sea farming. In: Fingerman M, Nagabhushanam R (eds) Recent advances in marine biotechnology, seafood and human health, Vol 7. Science Publishers, Enfield, NH, p 253-310

Osorio CR, Collins MD, Toranzo AE, Barja JL, Romalde JL (1999) 16S rRNA gene sequence analysis of Photobacterium damselae and nested PCR method for rapid detection of the causative agent of fish pasteurellosis. Appl Environ Microbiol 65:2942-2946

Editorial responsibility: Catherine Collins, Aberdeen, UK
Plumb JA (1999) Edwardsiella septicemias. In: Woo PTK, Bruno DW (eds) Fish diseases and disorders. Viral, bacterial and fungal infections. CABI Publishing, Wallingford, p 479-521

Romalde JL, López-Romalde $\mathrm{S}$, Ravelo $\mathrm{C}$, Magariños $\mathrm{B}$, Toranzo AE (2004) Development and validation of a PCRbased protocol for the detection of Pseudomonas anguilliseptica. Fish Pathol 39:33-41

Sakai T, Iida T, Osatomi K, Kanai K (2007) Detection of Type 1 fimbrial genes in fish pathogenic and non-pathogenic Edwardsiella tarda strains by PCR. Fish Pathol 42:115-117

Sakazaki R, Tamura K (1992) The genus Edwardsiella. In: Balows A, Trüper HG, Dworkin M, Harder W, Schleifer KH (eds) The prokaryotes. Springer-Verlag, Berlin, p 2737-2743

Thoesen JC (1994) Blue book, Vers 1. Suggested procedures for the detection and identification of certain finfish and shellfish pathogens, 4th edn. American Fisheries Society, Fish Health Section, Bethesda, MD

Toranzo AE (2007) Enfermedades bacterianas emergentes en cultivos marinos de Peces. In: Cerviño A, Guerra A, Pérez C (eds) Actas del XI Congreso Nacional de Acuicultura. Xunta de Galicia, Vigo, p 1033-1036

Toranzo AE, Romalde JL, Dopazo CP, Magariños B, Barja JL (2004) Disease trends in the primary marine fish species cultured in Spain: a 20-year study. World Aquac 35:35-38

> Toranzo AE, Magariños B, Romalde JL (2005) A review of the main bacterial fish diseases in mariculture systems. Aquaculture 246:37-61

Submitted: June 25, 2009; Accepted: January 19, 2010

Proofs received from author(s): April 7, 2010 